are among the smallest, if not actually the smallest, people upon the earth. There is no reason to suppose that these skeletons were selected in any way as exceptional specimens, yet they are both of them smaller than any other normal skeletons known, smaller certainly than the smallest Bushman skeleton in any Museum in this country, and smaller than any out of twenty-nine skeletons of the diminutive inhabitants of the Andaman Islands, of which the dimensions have been recorded by Prof. Flower in a previous paper communicated to the Institute. The most liberal calculation of the height of these two skeletons places that of the male at about an inch below 4 feet, and the female at less than an inch above. We may say 4 feet, or 1 '219 metre, as the average height of the two, while a living female of whom Emin Pasha has sent careful measurements is but $\mathrm{r} \cdot 164$ metre, or barely 3 feet ro inches. The results previously obtained from the measurements of about half-a-dozen living Akkas are not quite so low as these, varying from 1.216 to $1 \cdot 420$, and give a mean for both sexes of $1 \cdot 356$, or 4 feet $5 \frac{1}{2}$ inches. Schweinfurth's original measurements were unfortunately lost, and the numbers since obtained are quite insufficient for establishing the true average of the race, especially as it is not certain that they were all pure-bred specimens.

In the list given in the third edition of Topinard's "Anthropologie" (187.9) only two races appear which have a mean beight below I.500 metres, viz. the Negritos of the Andaman Islands I 478 , and the Bushmen I 404 . Of the real height of the former we have abundant and exact evidence, both from the living individuals and from skeletons, which clearly proves that they considerably exceed the Akkas in stature. That this is also the case with the Bushmen there is little doubt, although the measurements of this diminutive race are less numerous and carefully made.

The point of comparative size being settled, it remains to consider to what races the Akkas are most nearly allied. That they belong in all their essential characteristics to the black or Negroid branch of the human species there can be no doubt, in fact they exhibit all the essential characteristics of that branch even to exaggeration. With regard to the somewhat more rounded form of head (the cephalic index in these examples being $74^{\circ} 4$ and $77^{\circ} 9$ respectively), Hamy has long since pointed out that in equatorial Africa, extending from the west coast far into the interior, are scattered tribes of Negroes, distinguished from the majority of the inhabitants of the continent by this special cranial character, as well as by their smaller stature. The Akkas are grouped by Hamy and Quatrefages as members of this race, to which the distinctive name of "Negrillo" has been applied. Their small size has naturally led some anthropologists, including Schweinfurth, to ally them to the diminutive African race inhabiting the southern part of the continent-the Bushmen; but beyond certain characters met with in the whole Negroid branch, including the frizzly hair, there is little in common between them. The Bushmen are a very strongly marked race, and both their external appearance and osteological characters are so exceptional that they can never be confounded with any other. The natives of the Andaman Islands have also very distinctive characters, which they do not share with the Akkas, whose position all recent investigations show to be that assigned to them by Hamy as members of the Negrillo division of the Negroid branch of mankind. It is possible that these people gave origin to the stories of pygmies so common in the writings of the Greek poets and historians, and whose habitations were often placed near the sources of the Nile. The name "Akka," by which, according to Schweinfurth, the tribe now call themselves, has, singularly enough, been read by Mariette Pasha by the side of a portrait of a dwarf on a monument of the ancient Egyptian empire.

\section{REV. JOHN HEWITT JELLETT, D.D., D.C.L}

I $\mathrm{T}$ is with extreme regret that we announce the death of the Reverend the Provost of Trinity College, Dublin. He died last Sunday evening after a very short illness.

The Provost was present in his usual health at the Spring Commencements, which were held on the I4th inst. in the Hall of Trinity College; on the 16 th he was not quite well; on the 18 th some dangerous symptoms appeared ; and the end came, painlessly and unexpectedly, on the Igth inst.

John Hewitt Jellett was born at Cashel in the county of Tipperary on December 25, I8I7. He entered Trinity College, Dublin, when seventeen years of age. Obtaining a Scholarship in 1836 , he graduated as a Senior Moderator and Gold Medallist in Mathematics in 1837, and three years afterwards he obtained a Fellowship.

In 1848 , he was appointed to the Professorship of Natural Philosophy; in 1870 , on the death of the Rev. Dr. Luby, he was co-opted a Senior Fellow of Trinity College, and on the death of the Rev Dr. Lloyd, in $188 \mathrm{r}$, he was nominated by the Crown to the Provostship.

Twenty years ago he was made one of the Commissioners of National Education in Ireland, and he was President of the Royal Irish Academy from I 869 to 1873 .

In 1850 , Jellett published his well-known "Treatise on the Calcủlus of Variations," a subject which had engaged the attention of some of the noblest mathematical intellects of the world. The volume contains improvements of previously existing methods, which, had they been given as so many separate treatises, would in themselves have formed no ordinary title to fame; but the author's aim was rather to compile a memoir which would enable the earnest student to be on a level with the knowledge he had himself attained to, however little that aim might be to his own glory.

For this work the Royal Irish Academy awarded Jellett in $185 \mathrm{I}$ their Cunningham Gold Medal. In 1872 appeared the "Treatise on the Theory of Friction," a work well known and highly appreciated. In addition to these volumes a number of scientific memoirs were from time to time published by him in the Transactions of the Royal Irish Academy, and in Leonville's Journal de Mathématique, of which perhaps the more important were on the "Equilibrium and Motion of an Elastic Solid" and "On Researches in Chemical Optics."

Like other well-known mathematicians of the Dublin University, Jellett was as much thought of for his pulpit discourses as for his scientific memoirs. He was of good presence, had a clear articulation and a very persuasive style; and his appearance in the pulpit of the College chapel was always welcomed. When he dwelt on the moral difficulties of the Old Testament, none went their way without being impressed by the straightforward honesty of the man.

Occupying a very conspicuous position in a University city like Dublin, the Provost seemed to command the respect of all. Some perhaps there are who would have preferred that the head of so ancient a seat of learning should have taken no part in modern political strife ; but, even amid the feverish excitement of party warfare, the Provost of Trinity College, though he often fearlessly and eloquently put forward his own views, did so without giving offence to any.

Intimately associated, from the year 1834 , with the life of the College over which he at the last presided, the Provost knew much of, and was a prime mover in, many of the changes which have marked out a new life in the place. Within its walls he was known and respected, while the tribute to his memory paid by all classes of the Dublin citizens is a striking proof of how he was loved.

This is not the place to dwell on the intense loss his 
death brings to those who had experienced the charm of that hidden inner life which was known to his friends as both kind and just, affectionate and sympathetic.

\section{NOTES.}

THE retirement of the veteran Prof. Prestwich from the Chair of Geology at Oxford is an event which cannot be chronicled without regret. But it is pleasant to know that he relinquishes the post which he has dignified for so many years to find in the quiet of his country home that leisure and rest to which his long devotion to the cause of science so justly entitles him. He has crowned his professorial career by the publication of the splendid volume which completes his great work on geology. On the very day after the appearance of that volume the electors met at Oxford to select from the numerous candidates a successor to fill his place. His University and the science of geology may both be congralulated on their choice. Prof. Green, whom they have chosen, is one of the most accomplished geologists in the country, one who has been trained in the practical school of the Geological Survey, who has done admirable original work, and who possesses in no common measure the power of luminous exposition. He is gifted, moreover, with a faculty in which geologists are often singularly defective, that of mathematical investigation, and we may hope that one of the results of his transference to Oxford will be to afford him an opportunity of devoting himself to the attack of many geological problems from the mathematical side. He carries with him to his new sphere of labour the best wishes of all to whom the progress of geology and the cultivation of science at the Universities are clear.

ON May 27 next Prof. F. C. Donders, of Utrecht, will be seventy years of age. The law requires that he shall then resign his duties as Professor at the University and as Director of the Physiological Laboratory, and it is thought that men of science in all parts of the world may be glad to take the opportunity of expressing their appreciation of the great services Prof. Donders has rendered to the study of physiology and physiological optics. An infuential committee has been formed in Holland for the purpose of giving effect to this idea, and the proposal is that Prof. Donders' name should be connected in a permanent way with the spot where he has lived and worked for more than forty years, by the creation of a fund to be devoted to a scientific purpose, and to be known as the "Donders Memorial Fund." The uses to which the fund will be put, and the rules by which its administration will be governed, will of course be determined in accordance with the wishes of Prof. Donders. The Ophthalmological and Physiological Societies have taken the matter in hand in this country, and we have no doubt that the committees they have appointed will do their work satisfactorily. It ought not to be difficult for them to secure an adequate token of the respect felt in England for an illustrious man of science to whom the medical profession and the public are so deeply indebted. It is proposed that the amounts contributed by the several donors be not specified, but that they be grouped into a common sum for transmission to the Dutch Committee; and that the names of those contributing be inscribed in a suitable form for presentation to Prof. Donders. For this reason smaller as well as larger subscriptions will be acceptable. Subscriptions may be sent to Dr. Gerald F. Yeo, Secretary of the Committee of the Physiological Society (address King's College, London, W.C.), or to Dr. W. A. Brailey, Secretary of the Committee of the Ophthalmological Society of the United Kingdom (address-I I Old Burlington Street, London, W.). Subscriptions may also be sent to the office of this journal.
AT a meeting of the Royal Society of Edinburgh, held on January 3o, Profs. Clausius, Haeckel, and Mendeléeff were elected Honorary Fellows.

Sir JAmes PAGet, F.R.S., has consented to give the annua address to the students of the London Society for the Extension of University Teaching, at the Mansion House, on Saturday, March 3, at 3.30 p.m., under the presidency of the Lord Mayor. The subject of the address will be "Scientific Study."

A MARBLE medallion portrait of the distinguished palæontologist, Dr. Thomas Davidson, F.R.S., first chairman of the Brighton Museum Committee, was unveiled in the geological room of the Free Town Museum, Brighton, by the Mayor, Mr. E. Martin, on Friday, the $I 7^{\text {th }}$ inst. The medallion, which is much admired, is the work of Mr. Brock, A.R.A. It was presented to the town on behalf of the subscribers by Mr. Edward Crane, chairman of the Museum Committee, who referred in detail to Dr. Davidson's scrvices to science and to the Museum. Sir R. Owen sent a letter regretting that failing health prevented his paying the respect of personal attendance to the memory of his distinguished fellow-worker. Prof. Judd also wrote bearing cordial testimony to the skill and enthusiasm with which Dr. Davidson carried on his researches.

General Perrier, the most eminent French authority on geodesy, died at Montpellier on Monday at the age of fifty-five. $\mathrm{He}$ had attained the rank of Brigadier-General in the French army, and was at the head of the Geode tic Department at the War Office. He was a member of the Academy of Sciences.

THE relations of science and religion do not form one of those topics which we permit ourselves to discuss in NATURE. At the same time we may call attention to a series of three remarkable articles on "Darwinism and the Christian Faith" recently published in the Guardian (January 18 , January 25, and February I, I888), and now reprinted as a pamphlet. The author is anonymous, but is understood to be an Oxford College tutor, and Honorary Canon of Christ Church. The orthodoxy of the Guardian is, we believe, unimpeachable. We notice therefore with gratification that not only is Darwinism thoroughly accepted and lucidly expounded by the writer in the Guardian, but that he is an exceptionally well-informed and capable critic, whose scientific knowledge is varied and sound. The publication of these articles in the Guardian is a proof that the clergy as a body are not so unwilling to accept new scientific views as might be supposed were we to regard Dean Burgon as a fair sample of his class. The Guardian's contributor discusses the difficulty of reconciling the existence of a just, omnipotent, and omniscient God with the existence of pain and the ceaseless "struggle for existence," and à propos has a remark tinged with local colour which is worth reproducing. "And yet," he says, "man, who is so wise and good that he is always saying, with King Alphonso of Castile, 'If God had called me to His councils things would have been in better order,' has invented competitive examinations, which mean suffering and pain for all, without even a compensating 'survival of the fittest' or improvement of the race!" We believe that competitive examinations were invented by the Chinese, and introduced into Europe by Jesuit missionaries. The Chinese are celebrated among the nations of the world for the elaborate system of cruel tortures employed in their administration of justice. On the other hand, we owe tea and many other nice things to them.

THE annual winter meeting of the Department of Superintendence of the U.S. National Education Association was held lately at Washington. The most important topics treated were "How and to what extent can Manual Training be ingrafted on our System of Public Schools ?" and "How can the Qualifications of Teachers be determined ?" 